\title{
INSIGHT AND SELF-STIGMA IN PATIENTS WITH SCHIZOPHRENIA
}

\author{
Domagoj Vidović, Petrana Brečić, Maja Vilibić and Vlado Jukić
}

Department of Treatment and Rehabilitation, Vrapče University Psychiatric Hospital, Zagreb, Croatia

\begin{abstract}
SUMMARY - Poor insight and high level of self-stigma are often present among patients with schizophrenia and are related to poorer treatment adherence, poorer social function and rehabilitation, aggressive behavior, higher level of depression, social anxiety, lower quality of life and selfesteem. Reports on a relationship between insight and stigma are controversial. We examined the relationship of the level of insight and self-stigma in a sample of 149 patients with schizophrenia. Insight was measured with the Scale to assess Unawareness of Mental Disorder and self-stigma with the Internalized Stigma of Mental Illness. Results showed $88.6 \%$ of the patients to have high or moderate insight, with a mean value of 2.73. General insight showed the highest level (2.58) and insight in positive symptoms the lowest level (2.9). The self-stigma score in general was 2.13 , with stereotype endorsement being lowest (1.98). According to study results, $77.1 \%$ of patients felt minimal or low self-stigma across all subscales, except for stigma resistance subscale. Statistically significant correlation was found between insight and four subscales of self-stigma, while no correlation was found for the stigma resistance subscale only. These results imply the need of individually tailored antistigma and insight promoting programs for patients with schizophrenia.
\end{abstract}

Key words: Schizophrenia; Social stigma; Self concept; Personal satisfaction

\section{Introduction}

Approximately $50 \%-80 \%$ of patients with schizophrenia exhibit poor insight ${ }^{1,2}$. Such a high prevalence is found cross-culturally and during both early and later phases of illness. Lack of insight is highly prevalent even among those whose symptoms are remitting ${ }^{3}$. Despite these facts, it was only in the last two decades that the importance of insight has been highlighted and it is currently viewed as a multidimensional, continuous variable rather than "none-or all" as seen earlier. It includes the awareness of having a mental illness, its consequences, compliance with treatment and ability to label psychotic symptoms as pathological. Lack of insight has been reported to be

Correspondence to: Domagoj Vidovic, $M D$, Department of Treatment and Rehabilitation, Vrapče University Psychiatric Hospital, Bolnička 32, HR-10000, Zagreb, Croatia

E-mail: domagoj.vidovic@bolnica-vrapce.hr

Received October 5, 2015, accepted December 2, 2015 differently related to various measures of outcome. Research has shown that it is related to poorer treatment adherence, poorer social function, aggressive behavior and rehabilitation. On the other hand, better insight is related to lower self-esteem, lower quality of life and higher level of depression ${ }^{4}$.

Explanation for such a contradictory finding could be found in a specific way that the person accepts the "label" of mental illness. This has led us to the concept of self-stigmatization: a person's internalized feeling of stigma coming from acceptance of negative stereotypes and stigmatizing attitudes towards oneself. There is also a possibility of rejecting stigmatizing stereotypes and attitudes, which can result in empowerment with positive impact on outcome. The current model of selfstigma comprises five components: alienation, stereotype endorsement, discrimination experience, social withdrawal and stigma resistance. The prevalence of high self-stigma is about $60 \%$ and it is related to higher level of depression, social anxiety, lower quality of life 
and lower self-esteem ${ }^{5-7}$. Due to the high prevalence rates of both poor insight and self-stigma and their impact on outcome, it is important to examine the possible impact on the outcomes of illness.

The aim of the present study was to determine the relationship between the level of insight in illness and self-stigma. We wanted to test a hypothesis that higher insight would be related to a higher level of self-stigma.

\section{Patients and Methods}

The recruitment took place at Vrapče University Psychiatric Hospital in Zagreb between September 2012 and November 2014. Patients of both genders, aged 25-45 and diagnosed with schizophrenia were asked to take part in the study during after-care sessions. Exclusion criteria were diagnosis of alcohol or substance dependency, organic syndrome or severe somatic condition. Diagnoses were set by the Diagnostic and Statistical Manual of Mental Disorder IV (DSM IV) criteria. Overall, 149 patients were included in the study. The study was approved by the Hospital Ethics Committee. All participants signed a written informed consent.

General data were collected including age, gender, level of education, marital and employment status, number of previous hospitalizations and duration of illness. Insight was assessed with the Scale to assess Unawareness of Mental Disorder (SUMD), semi structured interview to evaluate global awareness of having a mental disorder, the achieved effects of medication, and social consequences of having a mental disorder, as well as specific insight into the symptoms and their attribution to the mental disorder. These dimensions of insight were rated with regard to the present level of insight on a 5-point Likert scale (1, "aware" to 5, "unaware"), with higher scores indicating poorer awareness. A shorter, 9-item version was used. This version has shown good reliability and validity. It comprises three items for general awareness, three items for positive and three items for negative symptoms ${ }^{8}$. Self-stigma was assessed with the Internalized Stigma of Mental Illness (ISMI). It is a 29-item paper and pencil questionnaire designed to assess subjective experience of stigma. It presents participants with first-person statements and asks them to rate them on a 4-point Likert scale as "Strongly disagree", "Disagree", "Agree" or "Strongly agree" with the statements related to having a mental illness. Items are summed to provide 4 major scale scores: alienation, which reflects feeling devalued as member of the society; stereotype endorsement, which reflects agreement with negative stereotypes of mental illness; discrimination experience, which reflects current mistreatment attributed to the biases of others; and social withdrawal, which reflects avoidance of others because of mental illness. The fifth additional score, stigma resistance, asks about the participant's perceived ability to deflect stigma and is coded reversely ${ }^{9}$. Spearman's correlation coefficient was used to assess correlation between insight and self-stigma. Statistics was done with the SPSS software (SPSS for Windows 20.0, SPSS, Chicago, IL, USA).

\section{Results}

In total 149 patients were included in the study, 107 (71.8\%) males and 42 (28.2\%) females, median age 34 (range 29-42). Medium or high level of education had $86.6 \%$ of patients, $85.9 \%$ were separated or single. Median duration of illness was 6 years, with $85.9 \%$ of patients having been hospitalized for up to five times. Demographic and clinical data are shown in Table 1.

More than 4/5 (88.6\%) of all patients had high or moderate insight, with a mean value of 2.73 for total insight. General insight showed the highest level (2.58) and insight in positive symptoms the lowest level (2.9) (Table 2). As shown in Table 3, the level of self-stigma in general was rather low (2.13), with stereotype endorsement showing the lowest result of 1.98. The stigma resistance subscale with the result of 2.37 due to reverse coding actually showed highest stigma. According to the results, almost $2 / 3$ of all patients felt minimal or low self-stigma across all subscales, except for stigma resistance subscale. As shown in Table 4, there was a statistically significant correlation between insight and four subscales of selfstigma, while no correlation was found for the stigma resistance subscale only.

\section{Discussion}

Results of the present study showed a relatively high level of insight among patients with schizo- 
phrenia. Prior researches usually found $50 \%-80 \%$ of patients to have poor insight into their illness ${ }^{1}$. The possible explanation for this finding is that patients included in this study were interviewed during aftercare sessions when insight is expected to be better. Gerretsen et al. report that insight improves during middle life, so it is possible that this had an impact on the level of insight ${ }^{10}$. Insight was lower for positive and negative symptoms compared with total insight and specific insight for effect of treatment, social consequences and illness itself. This can be explained by the fact that patients more easily recognize how something in general is happening with them, realize changes in social functioning and observe the impact of medication prior to defining positive and negative symptoms as part of illness. These results are consistent with the literature ${ }^{11,12}$.

Self-stigma measured with ISMI was much lower than reported earlier by Brohan and GAMIAN group

\section{Table 1. Sociodemographic and clinical data}

\begin{tabular}{|l|c|}
\hline $\mathrm{N}=149$ & $\mathrm{n}(\%)$ \\
\hline Age (yrs); median (IQR) & $34(29-42)$ \\
\hline Gender & $107(71.8)$ \\
\hline Male & $42(28.2)$ \\
\hline Female & \\
\hline Work status & $42(28.2)$ \\
\hline Employed/studying & $55(36.9)$ \\
\hline Unemployed & $52(34.9)$ \\
\hline Retired & \\
\hline Level of education & $20(13.4)$ \\
\hline Elementary school & $107(71.8)$ \\
\hline High school & $22(14.8)$ \\
\hline University & \\
\hline Marital status & $21(14.1)$ \\
\hline Married & $68(45.6)$ \\
\hline Single & $60(40.3)$ \\
\hline Separated & $6(2-12)$ \\
\hline Duration of illness, median (IQR) & \\
\hline Number of hospitalizations & $68(45.6)$ \\
\hline $1-2$ & $31(20.8)$ \\
\hline $3-4$ & $29(19.5)$ \\
\hline $5-9$ & $21(14.1)$ \\
\hline $10+$ & \\
\hline
\end{tabular}

(Croatia was included in the study) ${ }^{13}$; none of the patients had ISMI above 3 (strong self-stigma), while only $22.8 \%$ reported moderate self-stigma. High and moderate stigma resistance was lower than previously reported $(36.1 \%)^{14,15}$. The subscale of stereotype endorsement had lowest score, which is in accordance with previous reports $(87.3 \%)^{9,14-16}$. Alienation subscale showed the highest level of self-stigma, which is important for self-stigma interventions.

A shown in Table 4, correlation was found between insight and self-stigma, so lower insight was related to lower self-stigma. This finding supports prior reports ${ }^{4,17}$. Stronger correlation was found between self-stigma, general insight and insight into positive symptoms. The latter two strongly correlated to the subscale of alienation and discrimination experience. These results can be explained by better understanding of schizophrenia stigma. The name of illness and positive symptoms are the most stigmatizing features of schizophrenia. The name of illness is stigmatizing by itself and public picture of patients with schizophrenia is someone with positive symptoms such as hallucinations, delusions, grandiosity, while lay people rarely notice negative or cognitive symptoms as part of schizophrenia. Since self-stigma results from internalization of widespread, negative attitudes and prejudice about people with mental illness, it is reasonable to expect higher self-stigma for these two features of schizophrenia. Insight into negative symptoms strongly correlated to the subscale of social withdrawal and stereotype endorsement, with modest correlation for all subscales. According to earlier reports, the presence of negative symptoms in postacute phase raises self-stigma. Since patients included in this research were post-acute, this can explain this correlation $^{17,18}$. There was no correlation between stigma resistance subscale and insight, which implies that this subscale is related to some other variables yet to be determined ${ }^{19,20}$.

There were several limitations to the study important to consider. Due to the cross-sectional design of the study, we cannot draw definitive conclusions regarding causality. The majority of study patients were male and their age range was 25 to 45 years. Selfstigma was measured by the self-rating scale and all patients were enrolled in psychiatric treatment. Different relationships could be found in younger or older 
Table 2. Distribution on the Scale to assess Unawareness of Mental Disorder (SUMD)

\begin{tabular}{|l|c|c|c|c|c|}
\hline & Mean & SD & $\begin{array}{c}\text { High insight } \\
>3 \\
\mathrm{n}(\%)\end{array}$ & $\begin{array}{c}\text { Moderate insight } \\
3-4 \\
\mathrm{n}(\%)\end{array}$ & $\begin{array}{c}\text { Low insight } \\
4+ \\
\mathrm{n}(\%)\end{array}$ \\
\hline Total insight & 2.73 & 1.08 & $82(55.3)$ & $50(33.3)$ & $17(11.4)$ \\
\hline General insight & 2.58 & 1.05 & $55(36.9)$ & $83(55.7)$ & $11(7.3)$ \\
\hline Insight into positive symptoms & 2.9 & 1.11 & $86(57.7)$ & $36(24.1)$ & $27(18.1)$ \\
\hline Insight into negative symptoms & 2.84 & 1.07 & $82(55.03)$ & $43(28.8)$ & $24(16.1)$ \\
\hline
\end{tabular}

Table 3. Distribution of the Internalized Stigma of Mental Illness (ISMI)

\begin{tabular}{|l|c|c|c|c|c|c|}
\hline & Mean & SD & $\begin{array}{c}\text { Minimal >2 } \\
\mathrm{n}(\%)\end{array}$ & $\begin{array}{c}\text { Low 2-2.5 } \\
(\%)\end{array}$ & $\begin{array}{c}\text { Moderate 2.5-3 } \\
\mathrm{n}(\%)\end{array}$ & $\begin{array}{c}\text { Strong 3+ } \\
\mathrm{n}(\%)\end{array}$ \\
\hline ISMI & 2.13 & 0.93 & $60(40.2)$ & $55(36.9)$ & $34(22.8)$ & 0 \\
\hline Alienation & 2.23 & 0.97 & $69(46.3)$ & $24(16.1)$ & $40(26.8)$ & $16(10.7)$ \\
\hline $\begin{array}{l}\text { Stereotype } \\
\text { endorsement }\end{array}$ & 1.98 & 0.88 & $66(44.3)$ & $64(42.9)$ & $16(10.7)$ & $3(2.01)$ \\
\hline $\begin{array}{l}\text { Discrimination } \\
\text { experience }\end{array}$ & 2.08 & 0.9 & $73(48.9)$ & $35(23.5)$ & $33(22.1)$ & $8(5.4)$ \\
\hline Social withdrawal & 2.03 & 0.9 & $63(42.3)$ & $37(24.8)$ & $37(24.8)$ & $12(8.1)$ \\
\hline Stigma resistance & 2.37 & 0.99 & $51(34.2)$ & $44(29.5)$ & $39(26.2)$ & $15(10.1)$ \\
\hline
\end{tabular}

*coding reversely

Table 4. Correlation between insight and internalized stigma

\begin{tabular}{|l|c|c|c|c|c|c|}
\hline & \multicolumn{5}{|c|}{ Internalized self-stigma } \\
\hline \multirow{2}{*}{ Insight into } & Alienation & $\begin{array}{c}\text { Stereotype } \\
\text { endorsement }\end{array}$ & $\begin{array}{c}\text { Discrimination } \\
\text { experience }\end{array}$ & $\begin{array}{c}\text { Social } \\
\text { withdrawal }\end{array}$ & $\begin{array}{c}\text { Stigma } \\
\text { resistance }\end{array}$ & Total \\
\cline { 2 - 6 } General awareness & $-0.33^{* *}$ & $-0.24^{* *}$ & $-0.29^{* *}$ & $-0.28^{* *}$ & 0.08 & $-0.28^{* *}$ \\
\cline { 2 - 6 } Awareness of positive symptoms & $-0.25^{* *}$ & $-0.28^{* *}$ & $-0.23^{* *}$ & $-0.28^{* *}$ & 0.13 & $-0.23^{* *}$ \\
\hline Awareness of negative symptoms & $-0.31^{* *}$ & $-0.27^{* *}$ & $-0.31^{* *}$ & $-0.24^{* *}$ & 0.10 & $-0.28^{* *}$ \\
\hline
\end{tabular}

* $\mathrm{p}<0.05 ;{ }^{* *} \mathrm{p}<0.01$; Spearman's correlation coefficient

persons, or in a predominantly female sample. This could be specifically different among patients who decline regular treatment.

In conclusion, in this study, we determined the level of insight and self-stigma in patients with schizophrenia. To our knowledge, this is the first report on the level of insight in patients from Croatia. The hypothesis that insight and self-stigma are correlated was confirmed. Therefore, it is important to develop and implement tailored interventions to diminish the deleterious impact of self-stigma while improving insight ${ }^{21}$.

\section{References}

1. Amador XF, Strauss DH, Yale S A, Gorman JM. Awareness of illness in schizophrenia. Schizophr Bull. 1991;17(1):11332. doi: $10.1093 / \mathrm{schbul} / 17.1 .113$

2. Pini S, Dell'Osso L, Amador XF, Mastrocinque C, Saettoni $\mathrm{M}$, Cassano GB. Awareness of illness in patients with bipolar I disorder with or without comorbid anxiety disorders. Aust N Z J Psychiatry. 2003;37:355-61. doi: 10.1046/j.1440-1614 .2003.01188.x

3. Lysaker PH, Vohs J, Hillis JD, et al. Poor insight into schizophrenia: contributing factors, consequences and emerging treatment approaches. Expert Rev Neurother. 2013;13(7):78593. doi: 10.1586/14737175.2013.811150. 
4. Staring AB, Van der Gaag M, Van den Berge M, Duivenvoorden HJ, Mulder CL. Stigma moderates the associations of insight with depressed mood, low self-esteem, and low quality of life in patients with schizophrenia spectrum disorders. Schizophr Res. 2009;115:363-9. doi: 10.1016/j. schres.2009.06.015. Epub 2009 Jul 17.

5. Sibitz I, Amering M, Unger A, et al. The impact of the social network, stigma and empowerment on the quality of life in patients with schizophrenia. Eur Psychiatry. 2011;26:28-33. doi: 10.1016/j.eurpsy.2010.08.010. Epub 2010 Oct 30.

6. Lysaker PH, Yanos PT, Outcalt J, Roe D. Association of stigma, self-esteem, and symptoms with concurrent and prospective assessment of social anxiety in schizophrenia. Clin Schizophr Relat Psychoses. 2010;4(1):41-8. doi: 10.3371/ CSRP.4.1.3. doi: 10.3371/CSRP.4.1.3.

7. Yanos PT, Roe D, Markus K, Lysaker PH. Pathways between internalized stigma and outcomes related to recovery in schizophrenia spectrum disorders. Psychiatr Serv. 2008;59:1437-42. doi: 10.1176/appi.ps.59.12.1437

8. Michel P, Baumstarck K, Auquier P, et al. Psychometric properties of the abbreviated version of the Scale to Assess Unawareness in Mental Disorder in schizophrenia. BMC Psychiatry. 2013;13(1):229. doi: 10.1186/1471-244X-13-229.

9. Ritsher JB, Otilingam PG, Grajales M. Internalized stigma of mental illness: psychometric properties of a new measure. Psychiatry Res. 2003;121:31-49. DOI: http://dx.doi. org/10.1016/j.psychres.2003.08.008

10. Gerretsen P, Plitman E, Rajji TK, Graff-Guerrero A. The effects of aging on insight into illness in schizophrenia: a review. Int J Geriatr Psychiatry. 2014;29:1145-61. doi: 10.1002/ gps.4154. Epub 2014 Jul 23.

11. Mintz AR, Dobson KS, Romney DM. Insight in schizophrenia: a meta-analysis. Schizophr Res. 2003;61:75-88. DOI: http://dx.doi.org/10.1016/S0920-9964(02)00316-X

12. Mutsatsa SH, Joyce EM, Hutton SB, et al. Clinical correlates of early medication adherence: West London First Episode Schizophrenia study. Acta Psychiatr Scand. 2003;108:43946. DOI: 10.1046/j.0001-690X.2003.00193.x

13. Brohan E, Elgie R, Sartorius N, Thornicroft G. Self-stigma, empowerment and perceived discrimination among people with schizophrenia in 14 European countries: the GAMIAN-Europe study. Schizophr Res. 2010;122:232-8. doi: 10.1016/j.schres.2010.02.1065. Epub 2010 Mar 26.

14. Sibitz I, Unger A, Woppmann A, Zidek T, Amering M. Stigma resistance in patients with schizophrenia. Schizophr Bull. 2011;37:316-23. doi: 10.1093/schbul/sbp048. Epub 2009 Jun 1.

15. Lysaker PH, Tsai J YP. Associations of multiple domains of self-esteem with four dimensions of stigma in schizophrenia. Schizophr Res. 2008;98:194-200. doi: 10.1016/j. schres.2007.09.035

16. Brohan E, Slade M, Clement S, Thornicroft G. Experiences of mental illness stigma, prejudice and discrimination: a review of measures. BMC Health Serv Res. 2010;10:80. doi: 10.1186/1472-6963-10-80.

17. Cavelti M, Kvrgic S, Beck EM, Rüsch N, Vauth R. Selfstigma and its relationship with insight, demoralization, and clinical outcome among people with schizophrenia spectrum disorders. Compr Psychiatry. 2012;53(5):468-79. doi: 10.1016/j.comppsych.2011.08.001. Epub 2011 Sep 28.

18. Gerlinger G, Hauser M, De Hert M, Lacluyse K, Wampers $\mathrm{M}$, Correll CU. Personal stigma in schizophrenia spectrum disorders: a systematic review of prevalence rates, correlates, impact and interventions. World Psychiatry. 2013;12:155-64. doi: 10.1002/wps.20040.

19. Campellone TR, Caponigro JM, Kring AM. The power to resist: the relationship between power, stigma, and negative symptoms in schizophrenia. Psychiatry Res. 2014;215:280-5. doi: 10.1016/j.psychres.2013.11.020. Epub 2013 Nov 26.

20. Schrank B, Amering M, Hay AG, Weber M, Sibitz I. Insight, positive and negative symptoms, hope, depression and self-stigma: a comprehensive model of mutual influences in schizophrenia spectrum disorders. Epidemiol Psychiatr Sci. 2013:1-9. doi: 10.1017/S2045796013000322. Epub 2013 Jul 24.

21. Pijnenborg G, Van der Gaag M, Bockting CL, Van der Meer L, Aleman A. REFLEX, a social-cognitive group treatment to improve insight in schizophrenia: study protocol of a multi-center RCT. BMC Psychiatry. 2011;11:161. doi: 10.1186/1471-244X-11-161. 


\section{Sažetak \\ UVID I SAMOSTIGMA KOD OBOLJELIH OD SHIZOFRENIJE}

\section{Vidović, P. Brečić, M. Vilibić i V. Jukić}

Manjkav uvid i visoka razina samostigme često su prisutni kod oboljelih od shizofrenije, a povezani su sa slabijom suradljivošću, slabijim socijalnim funkcioniranjem, agresivnim ponašanjem, otežanom rehabilitacijom, višom razinom depresivnosti i socijalne tjeskobe, nižom kvalitetom života i manjkom samopouzdanja. Dosadašnja istraživanja utvrdila su kontradiktoran odnos uvida u bolest i samostigme. U ovom istraživanju ispitivali smo razinu uvida, samostigme i njihovu povezanost u uzorku od 149 bolesnika sa shizofrenijom. Prema dobivenim rezultatima, 88,6\% bolesnika imalo je visok ili umjeren uvid, sa srednjom vrijednošću od 2.73. Opći uvid pokazao je najvišu razinu, s rezultatom od 2.58, a uvid u pozitivne simptome je bio najniži, s rezultatom od 2.9. Ukupna samostigma bila je 2.13, a prihvaćanje stigme najniže, 1.98. Prema rezultatima, gotovo dvije trećine svih bolesnika osjećali su minimalnu ili nisku samostigmu prema svim podljestvicama, osim u podljestvici otpora stigmatizaciji. Nađena je statistički značajna korelacija između uvida i četiri podljestvice samostigme, a korelacija nije pronađena samo kod podljestvice otpora stigmatizaciji. Ovi rezultati potvrđuju hipotezu i impliciraju potrebu individualnog programa za smanjenje samostigme i promociju uvida za bolesnike sa shizofrenijom.

Ključne riječi: Shizofrenija; Drusttvena stigma; Sampoimanje; Osobno zadovoljstvo 